De Jure: Jurnal Hukum dan Syar'iah

Vol. 11, No. 2, 2019, h. 113-127

ISSN (Print): 2085-1618, ISSN (Online): 2528-1658

DOI: http://dx.doi.org/10.18860/j-fsh.v11i2.7999

Available online at http://ejournal.uin-malang.ac.id/index.php/syariah

\title{
Membuka Rahasia Bank Dalam Pembagian Harta Bersama Perspektif Maqashid Syariah
}

\author{
Risma Nur Arifah \\ UIN Maulana Malik Ibrahim Malang, Indonesia \\ mrs_ryzma@syariah.uin-malang.ac.id \\ Siti Zulaichah \\ UIN Maulana Malik Ibrahim Malang, Indonesia \\ M. Faiz Nashrullah \\ UIN Maulana Malik Ibrahim Malang, Indonesia
}

\begin{abstract}
:
Distribution of shared assets can lead to new conflicts if one party saves his assets in a bank account. Meanwhile, Law Number 10 of 1999 concerning Banking instructs banking business operators to keep their customers' and savings data confidential. This article is doctrinal legal research with the statutory approach and the conceptual approach. The results of this study indicate that bank secrecy is an instrument of legal protection against customers from various unauthorized parties. However, in the case of joint assets, bank secrets cannot be enforced as Constitutional Court Decision Number 64 / PUU-X / 2012 because the husband or wife of the customer is also the owner of the assets held in the bank.
\end{abstract}

Pembagian harta bersama dapat menimbulkan konflik baru jika salah satu pihak menyimpan hartanya di rekening bank. Sementara, Undang-Undang Nomor 10 Tahun 1999 tentang Perbankan memerintahkan pelaku usaha perbankan merahasiakan data nasabah dan simpanannya. Artikel ini bertujuan untuk mendeskripsikan dinamika regulasi rahasia bank terkait harta bersama. Artikel ini merupakan penelitian hukum doktrinal dengan pendekatan peraturan perundangundangan dan pendekatan konsep. Hasil kajian ini menunjukkan bahwa rahasia bank merupakan instrumen pelindungan hukum terhadap nasabah dari berbagai pihak yang tidak berkepentingan. Namun, dalam kasus harta bersama, rahasia bank tidak dapat diberlakukan sebagaimana Putusan Mahkamah Konstitusi Nomor 64/PUU-X/2012. Sebab suami atau istri nasabah juga merupakan pemilik dari harta yang disimpan di bank.

Kata Kunci : harta bersama; rahasia bank; maqashid shariah. 


\section{Pendahuluan}

Perkawinan merupakan ikatan lahir batin yang sangat kuat sebagaimana dirumuskan dalam Undang-Undang Nomor 1 Tahun 1974 tentang Perkawinan dan Kompilasi Hukum Islam. ${ }^{1}$ Hal ini menunjukkan bahwa ikatan perkawinan idealnya tidak mudah untuk lepas atau bercerai. Bahkan Undang-Undang Perkawinan menganut asas mempersulit terjadinya perceraian. Meskipun demikian, perkawinan dapat putus karena kematian, perceraian, dan atas keputusan pengadilan. ${ }^{2}$ Putusnya perkawinan menimbulkan berbagai akibat hukum, seperti nafkah iddah, hadhanah, hingga pembagian harta bersama. Secara umum, harta bersama diartikan sebagai kekayaan yang diperoleh sejak dilangsungkannya hingga putusnya perkawinan, baik karena kematian, perceraian, maupun putusan pengadilan. ${ }^{3}$ Harta bersama tidak hanya diperoleh selama perkawinan, tetapi juga bisa didapatkan dari hadiah, warisan, dan hibah. Utangpiutang yang timbul selama perkawinan juga dapat dijadikan objek harta bersama. $^{4}$

Penelitian harta bersama telah banyak dilakukan. Seperti kajian yang dilakukan oleh Besse Sugiswati yang membandingkan pengaturan tentang harta bersama dalam KUHPerdata, Kompilasi Hukum Islam dan Hukum Adat. Kajian in menunjukkan bahwa ada disparitas ketentuan tentang harta bersama yang berlaku di Indonesia. ${ }^{5}$ Konsep harta bersama juga berlaku bagi pasangan suami istri yang berbeda agama. Meskipun demikian, undang-undang belum memberikan ketentuan yang eksplisit. Jika terjadi konflik para pihak dapat memilih hukum yang dijadikan pedoman. ${ }^{6}$ Harta bersama juga berlaku dalam perkawinan poligami. Menurut Zaini dkk, harta bersama seorang suami yang beristri lebih dari satu berdiri sendiri dan terpisah satu sama lain. Masing-masing istri memiliki hak yang sama terhadap harta tersebut. Pembagian harta bersama seyogyanya dilakukan secara kekeluargaan. ${ }^{7}$ Objek harta bersama juga mengalami perluasan. Menurut Hamdi, harta bersama juga meliputi Asuransi TASPEN,

\footnotetext{
${ }^{1}$ Santoso, "Hakikat Perkawinan Menurut Undang-Undang Perkawinan, Hukum Islam,Dan Hukum Adat," YUDISIA : Jurnal Pemikiran Hukum Dan Hukum Islam 7, no. 2 (2016): 424.

2 Ramadhan Syahmedi Siregar, "Dampak Perceraian Yang Tidak Sesuai Dengan Prosedur Perundang-Undangan,” FITRAH:Jurnal Kajian Ilmu-ilmu Keislaman 1, no. 1 (2015): 164, https://doi.org/10.24952/fitrah.v1i1.333.

${ }^{3}$ Darmabrata, Wahjono, and Ahlas Sjarif Surini, Hukum Perkawinan Dan Keluarga Di Indonesia (Jakarta: UI Press, 2016), 76.

${ }^{4}$ Evi Djuniarti, "Hukum Harta Bersama Ditinjau dari Perspektif Undang-Undang Perkawinan dan KUH Perdata," Jurnal Penelitian Hukum De Jure 17, no. 4 (December 15, 2017): 446, https://doi.org/10.30641/dejure.2017.V17.445-461.

${ }^{5}$ Besse Sugiswati, "Konsepsi Harta Bersama Dari Perspektif Hukum Islam, Kitab Undang-Undang Hukum Perdata Dan Hukum Adat," Perspektif 19, no. 3 (September 28, 2014): 201, https://doi.org/10.30742/perspektif.v19i3.22.

${ }^{6}$ Erma Kartika Timur, "Pembagian Harta Bersama Perkawinan Dalam Perceraian Perkawinan Beda Agama Yang Dicatatkan," Rechtidee 12, no. 1 (June 30, 2017): 80, https://doi.org/10.21107/ri.v12i1.2871.

${ }^{7}$ Iman Jauhari Zaini, "Pembagian Harta Perkawinan Poligami Dalam Konteks Hukum Nasional (Studi Kasus Di Mahkamah Syar'iyah Jantho)," Jurnal Ilmu Hukum 1, no. 4 (October 10, 2013): 39, http://jurnal.unsyiah.ac.id/MIH/article/view/4566.
} 
Asuransi Tenaga Kerja, dana ASABRI, Dana Kecelakaan Lalu Lintas, dan Dana Asuransi kecelakaan. ${ }^{8}$

Pembagian harta bersama berpotensi besar menimbulkan konflik baru pasca perceraian. Menurut Muhammad Tigas Pradoto, para pihak dapat memilih menyelesaikan dengan cara musyawarah atau menempuh jalur hukum di pengadilan. ${ }^{9}$ Menurut Mursyid, pembagian harta bersama di pengadilan didasarkan pada al-Quran, al-Sunnah, pendapat ulama, peraturan perundangundangan, kondisi sosiologis masyarakat, kebutuhan istri dan anak. ${ }^{10}$ Menurut Mesraini, majelis hakim memberikan putusan tidak hanya sekedar berdasarkan peraturan yang ada, tetapi juga mempertimbangkan kesepakatan dari kedua belah pihak. $^{11}$ Kesepakatan bersama dapat mempermudah pelaksanaan putusan pengadilan di kemudian hari.

Secara normatif harta bersama di bagi secara sama $50 \%$ untuk suami dan $50 \%$ untuk istri. Meskipun demikian, menurut Kamarusdiana, majelis hakim dapat memberikan putusan dalam kasus pembagian harta bersama berbeda dari peraturan perundang-undangan. ${ }^{12}$ Majelis hakim mempertimbangkan kontribusi masing-masing pihak terhadap perolehan harta bersama menjadi salah satu faktor penentu dalam pembagian harta bersama. ${ }^{13}$ Misalnya, istri turut membantu mencari nafkah atau bahkan menjadi tulang punggu keluarga dapat memperoleh $70 \%$ harta bersama sedangkan laki-laki mendapatkan $30 \%$. Hal ini dilakukan demi terwujudnya keadilan bagi masyarakat. ${ }^{14}$ Sementara menurut Zikri Darussamin dan Armansyah, harta yang diperoleh istri dari pekerjaannya merupakan harta pribadi dan bukan harta bersama meskipun diperoleh pada saat perkawinan. ${ }^{15}$

Harta bersama yang berpindahtangan atau berada dalam penguasaan pihak ketiga juga menjadi problem dalam pembagian harta bersama. Penelitian Kadek

\footnotetext{
${ }^{8}$ Isnadul Hamdi, "Perluasan Makna Harta Bersama Perspektif Sosiologi Hukum Islam,” JURIS (Jurnal Ilmiah Syariah) 17, no. 1 (June 30, 2018): 82, https://doi.org/10.31958/juris.v17i1.1012.

9 Muhammad Tigas Pradoto, "Aspek Yuridis Pembagian Harta Bersama Dalam Perkawinan (tinjauan Hukum Islam Dan Hukum Perdata)," Jurnal Jurisprudence 4, no. 2 (June 3, 2017): 8990, https://doi.org/10.23917/jurisprudence.v4i2.4208.

${ }^{10}$ Mursyid Mursyid, "Ijtihad Hakim Dalam Penyelesaian Perkara Harta Bersama Di Mahkamah Syar'iyah Banda Aceh (Analisis Dengan Pendekatan Ushul Fiqh)," Ar Raniry: International Journal of Islamic Studies 1, no. 2 (December 1, 2014): 345, https://doi.org/10.20859/jar.v1i2.21.

11 Mesraini Mesraini, "Konsep Harta Bersama Dan Implementasinya Di Pengadilan Agama," AHKAM : Jurnal Ilmu Syariah 12, no. 1 (2012): 59, https://doi.org/10.15408/ajis.v12i1.980.

12 Kamarusdiana Kamarusdiana, "Disparity In The Judge's Ruling About Community Property Disputes After Divorce (An Analysis of The Verdict In The South Jakarta Religious Court, Religious Court of Jakarta And Supreme Court)," Jurnal Cita Hukum 6, no. 1 (June 27, 2018): 40, https://doi.org/10.15408/jch.v6i1.8266.

13 Arun Pratama, "Implementasi Percampuran Harta Bersama Dan Harta Bawaan Dalam Perkawinan (Studi Kasus Putusan Pengadilan Agama Nomor: 0189/Pdt.g/2017/Pa.Smg),” Jurnal Ius Constituendum 3, no. 1 (April 21, 2018): 24, https://doi.org/10.26623/jic.v3i1.861.

${ }^{14}$ Muhamad Beni Kurniawan, "Konsep Pembagian Harta Bersama Berdasarkan Kontribusi Dalam Perkawinan," AHKAM: Jurnal Ilmu Syariah 17, no. 2 (July 5, 2017): 370, https://doi.org/10.15408/ajis.v17i2.4741.

15 Zikri Darussamin and Armansyah Armansyah, "Hak Harta Bersama bagi Istri yang Bekerja Perspektif Maqashid asy-Syari'ah," Asy-Syir'ah 51, no. 2 (2017): 346, https://doi.org/10.14421/asy-syir'ah.2017.512.369-390.
} 
Setyawan Danarta menyatakan bahwa harta bersama dapat dijadikan hak tanggungan sesuai dengan hukum perkawinan masing-masing. ${ }^{16}$ Senada dengan hal ini, penelitian Tengku Erwinsyahbana dan Vivi Lia Falini Tanjung menunjukkan bahwa harta bersama dapat digunakan sebagai anggunan gadai. Menurut keduanya, perbuatan hukum yang berkaitan dengan harta bersama harus dilakukan atas persetujuan suami-istri. Tanpa adanya persetujuan kedua belah pihak, transaksi dinyatakan batal demi hukum. ${ }^{17}$ Harta bersama tidak dapat dihibahkan kepada orang lain, kecuali jika mendapat persetujuan pasangan dan tidak melebihi $1 / 3$ bagian. $^{18}$

Penguasaan harta bersama oleh salah satu pihak turut menghambat pembagian harta bersama secara damai. Problem ini terjadi karena adanya sikap apatis para pihak dan ketidaktahuan tentang hukum. ${ }^{19}$ Tidak hanya itu, pembagian harta bersama juga dapat terhambat karena regulasi yang ada. Seperti harta bersama yang disimpan salah satu pihak dalam rekening bank. Pasal 40 ayat (1) Undang-Undang Nomor 10 Tahun 1999 tentang Perbankan memerintahkan pelaku usaha perbankan merahasiakan data nasabah dan simpanannya. Konsekuensinya, bank tidak dibenarkan memberikan informasi apapun tanpa persetujuan dari nasabah. Meskipun dana yang disimpan merupakan harta bersama suami-istri. Pada tahun 2012, Mahkamah Konstitusi memberikan Putusan Nomor 64/PUU-X/2012 yang membatalkan keberlakuan pasal ini. Majelis hakim menilai bahwa harta bersama merupakan milik bersma dan masing-masing pihak berhak mengakses informasi atas dana tersebut.

Rahasia bank dan harta bersama masih menjadi tema menarik. Misalnya penelitian Winda Wijayanti, ${ }^{20}$ Kurnia Astrea Ningrum, ${ }^{21}$ kemudian Sri Harini Dwiyatmi dan Indirani Wauran. ${ }^{22}$ Namun, berbagai kajian ini belum menyentuh aspek hukum Islam, khususnya maqashid syariah. Artikel ini berargumen bahwa perlindungan yang diberikan oleh Mahkamah Konstitusi selaras dengan maqashid

16 Kadek Setyawan Danarta, "Karakteristik Pemasangan Hak Tanggungan Terhadap Harta Perkawinan," JURNAL MEDIA HUKUM DAN PERADILAN 5, no. 2 (October 30, 2019): 161, https://doi.org/10.29062/jmhp.v5i2.84.

17 Tengku Erwinsyahbana and Vivi Lia Valini Tanjung, "Kepastian Hukum Penggadaian Harta Bersama Tanpa Izin Dari Salah Satu Pasangan Dalam Perkawinan (Analisis Putusan Mahkamah Syar'iyah Nomor:0049/Pdt.G/2014/Ms-Aceh)," Varia Justicia 13, no. 1 (2017): 62, https://doi.org/10.31603/variajusticia.v13i1.1865.

18 Siti Misnar Abdul Jalil, "Kedudukan Harta Bersama yang Dihibahkan Ayah kepada Anak," Halu Oleo Law Review 2, no. 2 (September 30, 2018): 557, https://doi.org/10.33561/holrev.v2i2.4722.

${ }^{19}$ Zaiyad Zubaidi, "Problematika Pembagian Harta Bersama Di Samalanga-Bireuen," Jurnal ALIJTIMAIYYAH: Media Kajian Pengembangan Masyarakat Islam 5, no. 2 (October 9, 2019): 55, https://doi.org/10.22373/al-ijtimaiyyah.v5i2.4779.

20 Winda Wijayanti, "Kedudukan Istri dalam Pembagian Harta Bersama Akibat Putusnya Perkawinan Karena Perceraian Terkait Kerahasiaan Bank," Jurnal Konstitusi 10, no. 4 (May 20, 2016): 710, https://doi.org/10.31078/jk\%x.

${ }^{21}$ Kurnia Astrea Ningrum, "Rahasia Bank Terkait Harta Bersama Dalam Bentuk Simpanan Uang Dalam Bank," Kumpulan Jurnal Mahasiswa Fakultas Hukum 0, no. 0 (September 8, 2016): 1, http://hukum.studentjournal.ub.ac.id/index.php/hukum/article/view/1977.

${ }^{22}$ Sri Harini Dwiyatmi and Indirani Wauran, "Menembus Rahasia Bank Terkait Harta Bersama Dalam Perkawinan," Refleksi Hukum: Jurnal Ilmu Hukum 2, no. 1 (2017): 97, https://doi.org/10.24246/jrh.2017.v2.i1.p97-108. 
shariah berupa hifdz al-mal bagi suami atau istri. Mahkamah Konstitusi melalui putusannya memberikan jaminan perlindugan hukum kepada pasangan nasabah bank. Berdasarkan berbagai persoalan di atas, artikel ini bertujuan untuk mendeskripsikan dinamika regulasi rahasia bank terkait harta bersama. Kemudian mengkajianya melalui pespektif maqashid shariah.

\section{Metode Penelitian}

Penelitian ini termasuk dalam jenis penelitian hukum doktirnal. Ada dua pendekatan yang digunakan yaitu pendekatan perundang-undangan (statute approach) dan pendekatan konseptual (conceptual approach). Pendekatan perundang-undangan (statute approach) antara lain Putusan Mahkamah Konstitusi No. 64/PUU-X/2012, Undang-undang No. 1 Tahun 1974 tentang Perkawinan, Peraturan Pemerintah No. 9 Tahun 1975 tentang Pelaksanaan Undang-Undang No. 1 Tahun 1974, Undang-Undang No 10 Tahun 1998 tentang Perbankan. Pendekatan konseptual (conceptual approach) yaitu menelaah referensi terkait dengan tema konsep dan pengaturan harta harta bersama dan konsep pengaturan rahasia bank. Metode analisis bahan hukum ini dilakukan secara kualitatif. Secara kualitatif artinya menguraikan bahan secara beruntun dalam bentuk kalimat yang teratur, runtun, logis, tidak tumpang tindih, dan efektif, sehingga memudahkan pemahaman dan interpretasi data.

\section{Hasil dan Pembahasan Dinamika Regulasi Rahasia Bank di Indonesia}

Aktivitas utama perbankan adalah menghimpun dana masyarakat dalam bentuk simpanan dan menyalurkan kembali melalui aktivitas pembiayaan dan/atau bentuk lain demi terwujudnya kesejahteraan rakyat. Aktivitas ini tidak dapat berjalan dengan baik jika tidak ada kepercayaan dari masyarakat. Kepercayaan nasabah dapat dibangun melalui berbagai cara seperti informasi produk yang lengkap, akses lokasi yang mudah, kualitas pelayanan, dan ketersediaan fasilitas yang mendukung. ${ }^{23}$ Keamanan data dan dana nasabah juga menjadi faktor penting timbulnya kepercayaan masyarakat terhadap usaha perbankan. Pembobolan dana nasabah akan berpengaruh terhadap tingkat kepercayaan nasabah terhadap usaha perbankan. Untuk itu, Pelaku usaha perbankan, bank central, maupun dan pemerintah perlu melakukan berbagai upaya untuk melindungi segala sesuatu yang berkaitan dengan nasabah, baik identitas maupun simpanannya. ${ }^{24}$ Atas dasar ini, bank disebut sebagai agent of trust. Masyarakat akan tertarik menjadi nasabah disebabkan reputasi dan kredibilitas perbankan yang baik. ${ }^{25}$

\footnotetext{
${ }^{23}$ Mustika Delima and Metti Paramita, "Analisis Kemudahan Akses Terhadap Kepercayaan Masyarakat Pada Bank Syariah (Studi Bank BRI Syariah KCP Palabuhanratu)," NISBAH: JURNAL PERBANKAN SYARIAH 5, no. 1 (September 9, 2019): 81, https://doi.org/10.30997/jn.v5i1.1968.

24 Jesica Dalima, "Perlindungan Hukum Terhadap Nasabah Bank Akibat Terjadinya Pembobolan Rekening Melalui Internet Banking," LEX ET SOCIETATIS 6, no. 2 (July 3, 2018): 162, https://ejournal.unsrat.ac.id/index.php/lexetsocietatis/article/view/19965.

${ }_{25}$ Muhamad Djumhana, Rahasia bank: ketentuan dan penerapnnya di Indonesia (Bandung: Citra Aditya Bakti, 1996), 113.
} 
Bank wajib melindungi segala sesuatu tentang nasabah dan simpanannya meliputi: (1) Jumlah kredit; (2) Jumlah dan jenis rekening nasabah, baik berupa simpanan giro, deposito, tabanas, sertifikat dan surat berharga lainnya; (3) Pemindahan / transfer uang; (4) Pemberian garansi bank; (5) Pendiskontoan suratsurat berharga; dan (6) Pemberian kredit. ${ }^{26}$ Rahasia bank diperlukan karena hubungan antara bank dengan nasabah tidak seperti hubungan kontraktual biasa, akan tetapi dalam hubungan tersebut terdapat pula kewajiban bagi bank untuk tidak membuka rahasia nasabahnya kepada pihak lain kecuali jika ditentukan berbeda oleh perundang-undangan yang berlaku. ${ }^{27}$ Remy Syahdeni sebagaimana dikutip Ahmad Yasin mengatakan bahwa salah satu faktor yang dapat meningkatkan kepercayaan masyarakat terhadap perbankan adalah bisa tidaknya bank tersebut menyimpan rahasia perbankan, yaitu dengan tidak mengungkapkan keadaan keuangan dan transaksi nasabah serta keadaan lain dari nasabah yang bersangkutan kepada pihak lain. ${ }^{28}$ Memberikan informasi nasabah tidak hanya melanggar hukum melainkan juga bertentangan dengan etika. Hubungan antara bank dan nasabahnya lebih ditekankan pada aspek kejujuran. Kejujuran merupakan sikap etis pada yang tidak hanya merupakan tuntutan moral dan tuntutan efisiensi itu sendiri. ${ }^{29}$

Berbagai instrument hukum telah diberlakukan dalam rangka melindungi nasabah perbankan. Salah satunya adalah menerapkan rahasia bank. Pasal 40 ayat (1) Undang-Undang Nomor 10 Tahun 1998 tentang Perubahan Atas UndangUndang Nomor 7 Tahun 1992 tentang Perbankan menyatakan bahwa bank wajib merahasiakan segala informasi terkait nasabah penyimpan dan dana yang disimpan kecuali jika ditentukan lain berdasarkan undang-undang. Pelanggaran terhadap ketentuan ini dikenai pidana penjara dan denda. Implementasi regulasi rahasia bank kembali kepada moralitas pelaku usaha. Kondisi ini mendorong pemerintah membentuk Otoritas Jasa Keuangan (OJK) yang bertugas melakukan pengawasan terhadap usaha perbankan. Kehadikan OJK diharapkan mampu memaksimalkan perlindungan konsumen disektor perbankan. ${ }^{30}$

Secara teoritis, rahasia bank dibagi menjadi dua, rahasia yang bersifat mutlak dan rahasia yang bersifat relatif. Rahasia bank yang bersifat mutlak dalam hal ini bank sebagai lembaga keuangan harus mampu menjaga kerahasiaan yang dimiliki oleh nasabahnya dalam keadaan apapun baik biasa atau luar biasa. Sedangkan menurut teori rahasia bank yang bersifat relatif mempunyai pengertian, bahwasannya bank sebagai lembaga keuangan diperkenankan membuka rahasia tertentu dan bukan merupakan kewajiban bank untuk menyimpan rahasia tersebut, karena adanya alasan tertentu. ${ }^{31}$ Dalam undang-

\footnotetext{
${ }^{26}$ Djumhana, 164.

${ }^{27}$ Munir Fuady, Hukum perbankan modern (Bandung: Citra Aditya Bakti, 2003), 87.

28 Akhmad Yasin, "Keterkaitan Kerahasiaan Bank dan Pajak: Antara Kepentingan Negara dan Pribadi," Jurnal Konstitusi 16, no. 2 (July 11, 2019): 2014, https://doi.org/10.31078/jk1621.

${ }^{29}$ As Mahmoedin, Etika Bisnis Perbankan (Pustaka Sinar Harapan, 1994), 15.

${ }^{30}$ Ahmad Jailani, "Perlindungan Hukum Bagi Nasabah Terkait Dengan Rahasia Bank," Dinamika Hukum 25, no. 2 (2019): 9.

${ }^{31}$ John Bert Christian et al., "Analisis Hukum Atas Penerapan Rahasia Bank Di Indonesia Terkait Dengan Perlindungan Data Nasabah Berdasarkan Prinsip Kepercayaan Kepada Bank (Studi Pada
} 
undang perbankan diatur beberapa kondisi dimana bank diperbolehkan membuka rahasia data nasabah dan simpanannya. Adapun pengecualian terhadap rahasia bank sebagai berikut: Pertama, rahasia bank dapat dibuka karena kepentingan perpajakan. Pimpinan Bank Indonesia atas permintaan Menteri Keuangan berwenang memberikan perintah tertulis kepada bank disertai bukti-bukti yang mendukung. Sebagaimana diatur dalam Pasal 41 Undang-Undang Perbankan. Kedua, penyelesaian piutang Bank yang sudah diserahkan kepada Badan Urusan Piutang dan Lelang Negara/Panitia Urusan Piutang Negara. Sebagaimana diatur dalam Pasal 41 A Undang-Undang Perbankan.

Ketiga, kepentingan peradilan dalam perkara pidana. Pimpinan Bank Indonesia dapat memberikan izin kepada polisi, jaksa, atau hakim untuk memperoleh keterangan rekening tersangka atau terdakwa di bank. Sebagaimana diatur dalam Pasal 42 Undang-Undang Perbankan. Keempat, dalam perkara perdata antara bank dengan nasabah, direksi bank dapat memberikan informasi kepada pengadilan tentang keuangan nasabah. Sebagaimana diatur dalam Pasal 43 Undang-Undang Perbankan. Pembukaan rahasia bank hanya secara limitatif. Pembukaan data nasabah hanya dapat dilakukan apabila perkara perdata tersebut terjadi antara pihak bank dan nasabahnya. Jika pihak yang berperkara adalah nasabah bank dengan pihak ketiga Undang-Undang belum mengaturnya. Kelima, tukar menukar informasi antar Bank. Hal ini bertujuan menjaga iklim perbankan yang sehat dan menghindari kredit macet. Sebagaimana ditur dalam 44 UndangUndang Perbankan. Keenam, rahasia bank juga dapat dikecualikan atas dasar permintaan, persetujuan atau kuasa dari nasabah penyimpan yang dibuat secara tertulis. Sebagaimana diatur dalam Pasal 44 A ayat (1) Undang-Undang Perbankan. Ketujuh, permintaan ahli waris yang sah dari Nasabah Penyimpan yang telah meninggal dunia. Sebagaimana diatur dalam Pasal 44 A ayat (2) Undang-Undang Perbankan.

Berdasarkan uraian di atas, diketahui bahwa Undang-Undang Perbankan belum mengakomodir pengecualian rahasia bank dengan dasar kepentingan suami atau istri nasabah pasca perceraian. Konsekuensinya suami atau istri tidak dapat mengakses data nasabah beserta uang yang disimpan di rekening tanpa ada persetujuan dari nasabah. Hal ini memunculkan ketidakpastian dan ketidakadilan mengingat persetujuan nasabah berkaitan dengan iktikad baik. Dengan rahasia bank, salah satu pihak suami atau isteri yang merupakan nasabah bank dapat menguasai harta bersama dan dapat mengalihkan harta bersama tersebut tanpa sepengetahuan pihak lainnya. Rahasia bank juga menyebabkan proses pembuktian sengketa harta bersama membutuhkan waktu yang relatif lama. Karena perlu verifikasi status harta, apakah sebagai harta bersama atau harta bawaan. Kondisi ini tidak selaras dengan asas cepat, sederhana, dan biaya ringan.

Dalam kaitannya dengan rahasia bank, Mahkamah Konstitusi dalam Putusan MK Nomor 64/PUU-X/2012. Putusan ini keluar sebagai respon atas permohohan Pengujian Undang-Undang Nomor 7 Tahun 1992 Jo. Undang-Undang Nomor 10 Tahun 1998 tentang Perbankan terhadap Undang-Undang Dasar RI Tahun 1945.

Pt. Bank Cimb Niaga Tbk Cabang Medan)," USU LAW JOURNAL 4, no. 4 (December 14, 2016): 132. 
Berdasarkan putusan ini diketahui bahwa pada tahun 2012, pemohon mengajukan gugatan harta bersama di Mahkamah Syariah Kota Banda Aceh. Dalam gugatannya, pemohon mencantumkan sejumlah tabungan dan deposito di beberapa bank atas nama suami pemohon. Namun, bukti yang diajukan pemohon disanggah oleh suami pemohon. Atas dasar perbedaan pendapat ini Mahkamah Syariah mengirim permohonan informasi terkait data nasabah tersebut tetapi ditolak oleh pihak bank. Penolakan ini berkaitan dengan rahasia data nasabah sebagaimana diatur dalam Undang-Undang Nomor 7 Tahun 1992 dan Peraturan Bank Indonesia Nomor: 2/19/PBI/2000. Bahkan sejumlah deposito telah dialihkan oleh suami pemohon sebelum gugatan harta bersama disampaikan ke Mahkamah Syariah. Pihak bank juga tidak dapat menyampaikan aliran dana tersebut dengan dalih terdapat regulasi rahasia bank. ${ }^{32}$ Tindakan mengalihkan harta bersama tanpa sepengetahuan pihak lain bertentangan dengan Pasal 36 Undang-Undang Nomor 1 Tahun 1974 tentang Perkawinan ${ }^{33}$ Jo. Pasal 92 Kompilasi Hukum Islam yang membatasi kebebasan suami atau isteri untuk melakukan tindakan hukum terhadap harta bersama tanpa adanya persetujuan pihak lain. Hal ini merupakan manifestasi asas keseimbangan kedudukan suami istri dalam perkawinan.

Berdasarkan permohonan ini Mahkamah Konstitusi memberikan pertimbangan bahwa pemohon kehilangan hak konstitusional secara nyata, actual, dan spesifik. Keberlakuan regulasi rahasia bank yang diatur dalam UndangUndang Perbankan menghilangkan hak konstitusional pemohon sebagai seorang istri atas harta bersama. Karena pemohon tidak dapat mengetahui jumlah harta tersebut. Harta tersebut juga tidak boleh diambil secara sewenang-wenang oleh siapapun secara sepihak. Mahkamah Konstitusi juga menilai adanya hubungan sebab-akibat (causal verband) antara kerugian dimaksud dan berlakunya UndangUndang Perbankan. Apabila permohonan ini dikabulkan maka kerugian konstitusional tersebut tidak akan atau tidak lagi terjadi. Hak perlindungan ini dijamin dalam Pasal 28G ayat (1) dan Pasal 28H ayat (4) UUD 1945. Dua pasal ini menjamin bahwa setiap orang berhak tas perlindungan atas diri dan harta benda yang dimilikinya. Dan hak milik tersebut tidak dapat diambil secara sewenang-wenang oleh siapapun. Atas dasar petimbangan tersebut Mahkamah Konstitusi menyatakan bahwa Pasal 40 ayat (1) Undang-Undang Nomor 10 Tahun 1998 tentang Perubahan Atas Undang-Undang Nomor 7 tahun 1992 tentang Perbankan bertentangan dengan UUD RI Tahun 1945 sepanjang tidak dimaknai termasuk untuk kepentingan peradilan mengenai harta bersama dalam perkara perceraian. Pasal ini pula dinyatakan tidak mempunyai kekuatan hukum mengikat sepanjang tidak dimaknai termasuk untuk kepentingan peradilan mengenai harta bersama dalam perkara perceraian. ${ }^{34}$ Putusan Mahkamah Konstitusi Nomor 64/PUU-X/2012 bersifat conditionally constitutional atau konstitusional bersyarat. Hal ini berarti bahwa putusan Mahkamah Kontsitusi memandang bahwa suatu norma undang-undang dianggap konstitusional sepanjang dimaknai dan dijatuhkan sesuai dengan yang ditafsirkan oleh Mahkamah Konstitusi. Meskipun demikian, putusan Mahkamah Konstitusi tetap mengakui dan menjaga

\footnotetext{
${ }^{32}$ Putusan Mahkamah Konstitusi Nomor 64/PUU-X/2012

${ }^{33}$ Undang-Undang Nomor 1 Tahun 1974 tentang Perkawinan

${ }^{34}$ Putusan Mahkamah Konstitusi Nomor 64/PUU-X/2012
} 
perlindungan terhadap kerahasiaan bank, kepercayaan nasabah terhadap bank, dan kestabilan perekonomian nasional. ${ }^{35}$

Dengan menghubungkan aspek tujuan dari prinsip kerahasiaan bank dan kepemilikan harta bersama dalam perkawinan tersebut, harus diartikan bahwa suami atau istri nasabah penyimpan bukanlah pihak ketiga yang mungkin menyalahgunakan informasi mengenai simpanan. Bahkan sebagai pemilik, suami atau istri nasabah penyimpan bukan termasuk dalam sasaran dari prinsip kerahasiaan bank. Dengan demikian suami atau istri dari nasabah penyimpan seharusnya dapat mengakses informasi mengenai simpanan yang berupa harta bersama dalam perkawinan tersebut, sehingga dapat ditegaskan bahwa bank tidak memiliki kewajiban menjaga kerahasiaan simpanan di bank tersebut dari pemilik rekening simpanan itu sendiri. ${ }^{36}$ Harta bersama dalam perkawinan adalah milik bersama antara suami dan istri (yang tidak mengadakan perjanjian pemisahan harta perkawinan). Sehingga tidak ada kewajiban bank untuk menjaga kerahasiaan rekening (yang merupakan harta bersama) yang tersimpan pada suatu bank, dari suami atau istri nasabah yang namanya tertera pada rekening. Kerena suami atau istri dari pemilik rekening tersebut juga berkedudukan sebagai pemilik atas harta yang tersimpan dalam rekening. Dengan demikian, secara seseorang tidak dapat dibatasi haknya untuk mengakses harta kekayaannya sendiri.

\section{Membuka Rahasia Bank dalam Sengketa Harta Bersama Pespektif Maqashid Syariah}

Maqashid Syariah merupakan salah satu cabang dari ushul fiqh. Dalam kajian maqashid, suatu syariat dikaji lebih mendalam sehingga dapat dilihat hikmah-hikmah disyariatkannya suatu perintah atau larangan. Imam Ibnu 'Asyur memberikan definisi maqashid syariah sebagai hikmah atau makna yang bersumber dari Allah Swt. yang terjadi pada seluruh atau mayoritas ketentuanNya. ${ }^{37}$ Imam asy-Syatibi menjelaskan bahwa maqashid syariah dibagi menjadi lima prinsip umum atau biasa dikenal dengan istilah kulliyat al-khamsah. Kelima aspek tersebut adalah hifdz al-din (menjaga agama), hifdz al-nafs (menjaga jiwa), hifdz al-aql (menjaga pikiran), hifdz al-mal (menjaga harta), dan hifdz alnasl/nasab (menjaga keturunan). ${ }^{38}$

Dari kelima prinsip maqashid tersebut, pembahasan tentang harta lebih condong ke kajian hifdz al-mal (menjaga harta). Maksud dari menjaga harta di sini adalah syariat Islam membuat aturan tentang tata cara memperoleh harta yang benar sesuai dengan ketentuan Allah Swt. dalam al-Qur'an ataupun hadis Rasulullah Saw. ${ }^{39}$ Islam melarang manusia untuk memperoleh atau sekedar mengambil manfaat dari harta yang bukan miliknya. Meskipun pada hakekatnya

\footnotetext{
${ }^{35}$ Wijayanti, "Kedudukan Istri dalam Pembagian Harta Bersama Akibat Putusnya Perkawinan Karena Perceraian Terkait Kerahasiaan Bank," 722.

${ }^{36}$ Dwiyatmi and Wauran, "Menembus rahasia bank," 106.

${ }^{37}$ Ismail Hasani, Nadzoriyyatul Maqashid 'inda al-Imam Ibnu 'Ashur (Cairo: International Institute of Islamic Though, 1995), 114.

${ }^{38}$ Ahmad Risuni, Nadzoriyyatul Maqashid 'inda al-Imam Asy-Syatibi (Cairo: International Institute of Islamic Though, 1995), 5.

${ }^{39}$ Abdul Majid Najjar, Maqashid Asy-Syariah Bi Ab'adin Jadidah (Beirut: Dar al-'Arab al-Islamy, 2008), 187.
} 
semua yang ada di dunia adalah milik Allah SWT. Namun ajaran Islam tetap mengatur bagaimana manusia menggunakan dan memanfaatkan fasilitas yang diberikan oleh Allah SWT. semua aturan yang dibuat terkait pengelolaan harta tersebut semata-mata bertujuan untuk kemaslahatan kehidupan manusia di dunia.

Ulama membagi hifdz al-mal menjadi lima kategori: 1) Menjaga harta dengan cara melakukan upaya untuk memperoleh sesuai syariat Islam, 2) Menjaga harta dengan cara melindunginya dari kerusakan dan ketiadaan, 3) Menjaga harta dengan cara melindungi hak kepemilikan, 4) Menjaga harta dengan cara mnjaga keutuhan nilai barang tersebut, 5) Menjaga harta dengan cara meredarkan dan mendistribusikan harta sesuai aturan syariat Islam. ${ }^{40}$ Kelima jenis maqashid hifdz al-mal di atas harus diaplikasikan oleh umat Islam jika ingin perekonomian umat berjalan dengan baik. Satu aspek saja diabaikan, maka perekonomian masyarakat akan terhambat. Misalnya beberapa golongan orang dengan sengaja tidak meredarkan dan mendistribusikan harta atau biasa dikenal dengan istilah menimbun harta, maka harga barang di pasar akan melonjak dan memberatkan para konsumen. Maka dari itu, seluruh aspek dalam hifdzu mal di atas harus terlaksana dengan baik.

Kebutuhan manusia akan harta berbeda-beda antara satu orang dengan orang lainnya. Perbedaan tersebut menyesuaikan dengan situasi dan kondisi yang ada saat melaksanakan transaksi atau syariat hifdz al-mal. Ada tiga tingkatan maqashid syariah hifdz al-mal antara lain dharuriyat (primer), hajiiyat (sekunder), dan tahsiniyat (tersier). Misalnya kebutuhan manusia akan tempat tinggal untuk melindungi diri dari panas ataupun dingin, maka kebutuhan ini masuk kategori dharuriyat karena tanpa tempat tinggal kehidupan manusia akan rusak dan kacau, sedangkan kebutuhan manusia akan tempat tinggal dengan luas sekian dan fasilitas-fasilitas tertentu merupakan contoh dari kategori hajjiyat, kemudian kebutuhan manusia untuk mengisi tempat tinggal dengan perabotperabot tambahan masuk dalam kategori tahsiniyyat. Urutan maqashid atau kebutuhan tersebut dapat berubah sewaktu-waktu menyesuaikan dengan situasi dan kondisi yang ada. Beberapa ulama menyebutkan bahwa urutan di atas bukanlah bagian dari maqashid karena selalu tetap dan tidak berubah, adapun yang berubah adalah wasail atau sarana untuk memenuhi maqashid tersebut. ${ }^{41}$

Jika dianalisis secara rinci, ada dua hak yang seakan-akan saling bertentangan dalam kasus di atas. Pertama, hak bank untuk melindungi data dan tabungan nasabahnya dari pihak-pihak luar. Alasan pihak bank ini merujuk pada Undang-Undang Nomor 7 Tahun 1992 Jo. Undang-Undang Nomor 10 Tahun 1998 Tentang Perbankan. Kedua, hak seorang suami atau istri untuk mengakses harta bersama yang didapat selama perkawinan pasca cerai dengan pasangannya. Akses tersebut menjadi terhambat jika salah satu pihak suami/istri menyimpan harta bersama di bank, padahal baik suami atau istri keduanya sama-sama memiliki hak untuk mengakses harta bersama tanpa ada batasan dari pihak lain. Dalam kajian maqashid, kedua hak tersebut masuk dalam kategori menjaga harta atau hifdz al-mal.

\footnotetext{
${ }^{40}$ Najjar, 185-86.

${ }^{41}$ Jamaludin 'Athiyah, Nahwa Taf'il al-Maqashid (Damaskus: Dar al-Fikr, 2003), 51.
} 
Ketentuan dan dasar hukum mengenai harta bersama tidak dapat ditemukan baik di al-Qur'an ataupun Hadis, artinya konsep harta bersama adalah murni hasil ijtihad para ulama. Ketentuan mengenai harta bersama di Indonesia tercantum dalam Kompilasi Hukum Islam atau Kepres No.1 Tahun 1992 Buku I tentang Perkawinan. Meskipun masuk dalam pembahasan perkawinan, sebenarnya harta bersama dianggap kurang sinkron dengan tujuan perkawinan, yakni membangun keluarga sakinah, mawaddah, warahmah. Konsep harta bersama lebih condong ke hukum ekonomi karena murni bercorak business oriented. Hal tersebut dikarenakan harta bersama tidaklah menjadi suatu masalah saat suatu perkawinan masih berlangsung, namun akan memiliki dampak saat perkawinan telah usai, baik karena pisah ataupun meninggal. Dalam kajian ekonomi, harta bersama identik dengan praktik syirkah, yakni kerja sama antara dua orang atau lebih yang keuntungannya di bagi rata antar kedua belah pihak. ${ }^{42}$

Rahasia bank adalah upaya dari bank untuk melindungi segala sesuatu yang berhubungan dengan keterangan mengenai nasabah penyimpan dan simpanannya. Ketentuan mengenai rahasia bank terdapat dalam Pasal 40 Ayat 1 dan 2 UU No. 10 Tahun 1998 Tentang Perbankan. Jika diperhatikan secara teliti, sebenarnya terdapat pengecualian dalam kasus pembukaan rahasia yang telah diakomodir oleh Undang-Undang. Dalam Pasal 40 Ayat 1 dijelaskan bahwa rahasia bank dapat dibuka berdasarkan pasal 41, pasal 41A, pasal 42, dan pasal 43. Beberapa alasan yang menjadikan rahasia bank dapat dibuka diantaranya: kepentingan perpajakan, penyelesaian piutang, kepentingan peradilan baik kasus pidana, dan dalam hal nasabah telah meninggal dunia. Ketentuan rahasia bank dalam kajian maqashid masuk dalam kategori hifdz al-mal jenis mejaga harta dengan cara melindunginya dari kerusakan atau ketiadaan. Pihak bank menutup akses data nasabah bagi orang lain semata-mata karena melindungi harta nasabah dari pihak yang tidak bertanggung jawab, bukan melindungi nasabah dari kewajibannya terhadap Negara atau orang lain.

Dalam kajian maqashid syariah, jika terjadi benturan antara satu maqashid dengan maqashid yang lain, maka dipilih maqashid yang paling kecil resiko kerusakannya. Misalnya antara maqashid dharuriyat bertentangan dengan hajjiyat maka diutamakan maqashid yang dharuriyat karena kalau ditinggal akan menyebabkan kacaunya kehidupan manusia. Sedangkan maqashid hajjiyat, kalau ditinggal hanya menyebabkan kehidupan manusia sulit dan tidak sampai kondisi rusak atau kacau. ${ }^{43}$ Jika terjadi pertentangan sesame maqashid dharuriyat maka dipilih maqashid yang paling kecil mafsadah-nya. Misalnya seseorang dirampok di tengah jalan dan diberi pilihan harta atau nyawa, maka dia harus lebih memilih nyawa, karena harta sangat banyak di dunia dan dapat dicari kembali sedangkan nyawa manusia hanya satu saja. Contoh lain ketika seseorang dipaksa untuk mengucapkan kalimat murtad, atau dipaksa meminum minuman keras, maka ia diperbolehkan melakukan larangan agama untuk tujuan melindungi diri, karena

\footnotetext{
42 Zikri Darussamin and Armansyah Armansyah, "Hak Harta Bersama bagi Istri yang Bekerja Perspektif Maqashid asy-Syari'ah,” Asy-Syir'ah 51, no. 2 (2017): 358, https://doi.org/10.14421/asy-syir'ah.2017.512.369-390.

${ }^{43}$ Risuni, Nadzoriyyatul Maqashid 'inda al-Imam Asy-Syatibi, 162.
} 
adanya kebolehan melakukan larangan tersebut dalam keadaan dipaksa. Namun ketentuan ini tidak berlaku dalam kasus zina. ${ }^{44}$

Berdasarkan prinsip maqashid di atas, maka dalam kasus pembukaan rahasia bank untuk tujuan harta bersama diperbolehkan. Meskipun kedua pihak sama-sama memiliki maqashid atau tujuan baik, namun maqashid dalam tuntutan suami/istri mengakses data harta bersama lebih diutamakan daripada maqashid pihak bank menjaga data nasabah dengan cara melindungi keutuhan harta. Alasannya karena jika pihak penuntut tidak diberikan akses mengetahui jumlah harta bersama, maka ia akan dirugikan dari segi finansial dan kedudukan. Sedangkan pihak bank secara yuridis dan legal memang dibenarkan untuk membuka rahasia nasabah jika alasannya sesuai dengan Undang-Undang yang berlaku, meskipun alasan harta bersama belum masuk dalam pengecualian tersebut. Dalam hal ini pihak nasabah juga tidak dirugikan dari segi apapun dengan bocornya data ke mantan suami/istri karena memang seharusnya tidak ada rahasia dalam harta bersama suami-istri. Meski demikian, bank harus benar-benar meyakini bahwa pihak yang melakukan penuntutan pembukaan rahasia adalah pasangan sah atau mantan pasangan sah nasabahnya.

Senada dengan analisis maqashid syariah adalah putusan Mahkamah Konstitusi dalam Putusan MK Nomor 64/PUU-X/2012. Putusan ini dikeluarkan karena adanya permohohan Pengujian Undang-Undang Nomor 7 Tahun 1992 Jo. Undang-Undang Nomor 10 Tahun 1998 tentang Perbankan terhadap UndangUndang Dasar RI Tahun 1945. Amar putusan MK menyebutkan bahwa pasal 40 (1) dianggap bertentangan dengan Undang-Undang Dasar 1945 dan tidak memiliki kekuatan hukum sepanjang tidak dimaknai termasuk untuk kepentingan peradilan mengenai harta bersama dalam perkara perceraian. Artinya pasal 40 (1) harus mencakup kebolehan pembukaan rahasia bank untuk kepentingan peradilan terkait kasus harta bersama dalam perkara perceraian. Putusan Mahkamah Konstitusi ini sesuai dengan kaidah dalam upaya hifdzu mal, yakni adanya kejelasan status harta. ${ }^{45}$ Dengan tidak adanya kejelasan akses harta bersama ke rekening nasabah, maka hak salah satu pemilik harta bersama telah dirampas. Maka dari itu setiap akad menyangkut harta harus jelas statusnya.

Dalam kajian hukum Islam, pembukaan rahasia rekening nasabah berkaitan dengan harta bersama secara definisi diatur dalam hukum perkawinan karena menyangkut harta bersama. Namun secara spesifik materi hukum harta bersama sangat erat kaitannya dengan hukum ekonomi karena orientasinya lebih ke business. Kajian maqashid dalam hal bisnis memiliki dua model, yakni dari sisi bagaimana mendapatkannya ( $m i n$ janib al-wujud), dan dari sisi memelihara atau mempertahankan harta yang dimiliki (min janib al-'adam). ${ }^{46}$ Keduanya samasama dijamin oleh hukum Islam. Maka dari itu, apapun akad atau aturan yang menghalangi seorang untuk mempertahankan hartanya dianggap tidak sesuai dengan maqashid syariah hifdz al-mal.

\footnotetext{
44 'Athiyah, Nahwa Taf'il al-Maqashid, 28.

${ }^{45}$ Oni Sahroni and Adiwarman A. Karim, Maqashid Bisnis \& Keuangan Islam : Sintesis Fikih Dan Ekonomi (Jakarta: Rajawali Pers, 2015), 66.

${ }^{46}$ Sahroni and Karim, 65.
} 


\section{Kesimpulan}

Berdasarkan uraian di atas dapat disimpulkan bahwa rahasia bank merupakan instrumen pelindungan hukum terhadap nasabah dari berbagai pihak yang tidak berkepentingan. Namun, dalam kasus harta bersama, rahasia bank tidak dapat diberlakukan sebagaimana Putusan Mahkamah Konstitusi Nomor 64/PUU-X/2012. Sebab suami atau istri nasabah juga merupakan pemilik dari harta yang disimpan di bank. Suami atau istri nasabah juga berkedudukan sebagai pemilik atas harta yang tersimpan dalam rekening. Dengan demikian, secara seseorang tidak dapat dibatasi haknya untuk mengakses harta kekayaannya sendiri. Putusan ini merupakan salah satu dasar fundamental bagi para pencari keadilan atas harta yang di dapatkan bersama selama perkawinan. Dilihat dari aspek maqashid syariah, Putusan Mahakamah Konstitusi selaras dengan upaya hifdz al-mal dimana seseorang tidak boleh mengambil harta atau hak milik orang lain secara sewenang-wenang.

\section{Daftar Pustaka}

'Athiyah, Jamaludin. Nahwa Taf'il al-Maqashid. Damaskus: Dar al-Fikr, 2003. Christian, John Bert, Bismar Nasution, Suhaidi Suhaidi, and Mahmul Siregar. "Analisis Hukum Atas Penerapan Rahasia Bank Di Indonesia Terkait Dengan Perlindungan Data Nasabah Berdasarkan Prinsip Kepercayaan Kepada Bank (Studi Pada Pt. Bank Cimb Niaga Tbk Cabang Medan)." USU LAW JOURNAL 4, no. 4 (December 14, 2016): 132-141-141.

Dalima, Jesica. "Perlindungan Hukum Terhadap Nasabah Bank Akibat Terjadinya Pembobolan Rekening Melalui Internet Banking." LEX ET SOCIETATIS 6, no. $\quad 2 \quad$ (July 2018 ). https://ejournal.unsrat.ac.id/index.php/lexetsocietatis/article/view/19965.

Danarta, Kadek Setyawan. "Karakteristik Pemasangan Hak Tanggungan Terhadap Harta Perkawinan." JURNAL MEDIA HUKUM DAN PERADILAN 5, no. 2 (October 30, 2019): 161-74. https://doi.org/10.29062/jmhp.v5i2.84.

Darmabrata, Wahjono, and Ahlas Sjarif Surini. Hukum Perkawinan Dan Keluarga Di Indonesia. Jakarta: UI Press, 2016.

Darussamin, Zikri, and Armansyah Armansyah. "Hak Harta Bersama bagi Istri yang Bekerja Perspektif Maqashid asy-Syari'ah." Asy-Syir'ah 51, no. 2 (2017): 345-66. https://doi.org/10.14421/asy-syir'ah.2017.512.369-390.

Delima, Mustika, and Metti Paramita. "Analisis Kemudahan Akses Terhadap Kepercayaan Masyarakat Pada Bank Syariah (Studi Bank BRI Syariah KCP Palabuhanratu)." NISBAH: JURNAL PERBANKAN SYARIAH 5, no. 1 (September 9, 2019): 75-82. https://doi.org/10.30997/jn.v5i1.1968.

Djumhana, Muhamad. Rahasia bank: ketentuan dan penerapnnya di Indonesia. Bandung: Citra Aditya Bakti, 1996.

Djuniarti, Evi. "Hukum Harta Bersama Ditinjau dari Perspektif Undang-Undang Perkawinan dan KUH Perdata." Jurnal Penelitian Hukum De Jure 17, no. 4 (December 15, 2017): 445-61. https://doi.org/10.30641/dejure.2017.V17.445-461. 
Dwiyatmi, Sri Harini, and Indirani Wauran. "Menembus Rahasia Bank Terkait Harta Bersama Dalam Perkawinan." Refleksi Hukum: Jurnal Ilmu Hukum 2, no. 1 (2017): 97-108. https://doi.org/10.24246/jrh.2017.v2.i1.p97-108.

Erwinsyahbana, Tengku, and Vivi Lia Valini Tanjung. "Kepastian Hukum Penggadaian Harta Bersama Tanpa Izin Dari Salah Satu Pasangan Dalam Perkawinan (Analisis Putusan Mahkamah Syar'iyah Nomor :0049/Pdt.G/2014/Ms-Aceh)." Varia Justicia 13, no. 1 (2017): 4764. https://doi.org/10.31603/variajusticia.v13i1.1865.

Fuady, Munir. Hukum perbankan modern. Bandung: Citra Aditya Bakti, 2003.

Hamdi, Isnadul. "Perluasan Makna Harta Bersama Perspektif Sosiologi Hukum Islam." JURIS (Jurnal Ilmiah Syariah) 17, no. 1 (June 30, 2018): 63-83. https://doi.org/10.31958/juris.v17i1.1012.

Hasani, Ismail. Nadzoriyyatul Maqashid 'inda al-Imam Ibnu 'Ashur. Cairo: International Institute of Islamic Though, 1995.

Jailani, Ahmad. "Perlindungan Hukum Bagi Nasabah Terkait Dengan Rahasia Bank." Dinamika Hukum 25, no. 2 (2019).

Jalil, Siti Misnar Abdul. "Kedudukan Harta Bersama yang Dihibahkan Ayah kepada Anak." Halu Oleo Law Review 2, no. 2 (September 30, 2018): 556-67. https://doi.org/10.33561/holrev.v2i2.4722.

Kamarusdiana, Kamarusdiana. "Disparity In The Judge's Ruling About Community Property Disputes After Divorce (An Analysis of The Verdict In The South Jakarta Religious Court, Religious Court of Jakarta And Supreme Court)." Jurnal Cita Hukum 6, no. 1 (June 27, 2018): 19-44-44. https://doi.org/10.15408/jch.v6i1.8266.

Kurniawan, Muhamad Beni. "Konsep Pembagian Harta Bersama Berdasarkan Kontribusi Dalam Perkawinan.” AHKAM : Jurnal Ilmu Syariah 17, no. 2 (July 5, 2017). https://doi.org/10.15408/ajis.v17i2.4741.

Mahmoedin, As. Etika Bisnis Perbankan. Pustaka Sinar Harapan, 1994.

Mesraini, Mesraini. "Konsep Harta Bersama Dan Implementasinya Di Pengadilan Agama." AHKAM: Jurnal Ilmu Syariah 12, no. 1 (2012). https://doi.org/10.15408/ajis.v12i1.980.

Mursyid, Mursyid. "Ijtihad Hakim Dalam Penyelesaian Perkara Harta Bersama Di Mahkamah Syar'iyah Banda Aceh (Analisis Dengan Pendekatan Ushul Fiqh)." Ar Raniry: International Journal of Islamic Studies 1, no. 2 (December 1, 2014): 317-46. https://doi.org/10.20859/jar.v1i2.21.

Najjar, Abdul Majid. Maqashid Asy-Syariah Bi Ab'adin Jadidah. Beirut: Dar al'Arab al-Islamy, 2008.

Ningrum, Kurnia Astrea. "Rahasia Bank Terkait Harta Bersama Dalam Bentuk Simpanan Uang Dalam Bank." Kumpulan Jurnal Mahasiswa Fakultas Hukum 0, no. 0 (September 8, 2016). http://hukum.studentjournal.ub.ac.id/index.php/hukum/article/view/1977.

Pradoto, Muhammad Tigas. "Aspek Yuridis Pembagian Harta Bersama Dalam Perkawinan (tinjauan Hukum Islam Dan Hukum Perdata)." Jurnal Jurisprudence 4, no. 2 (June 3, 2017): 85-91-91. https://doi.org/10.23917/jurisprudence.v4i2.4208. 
Pratama, Arun. "Implementasi Percampuran Harta Bersama Dan Harta Bawaan Dalam Perkawinan (Studi Kasus Putusan Pengadilan Agama Nomor: 0189/Pdt.g/2017/Pa.Smg)." Jurnal Ius Constituendum 3, no. 1 (April 21, 2018): 15-26. https://doi.org/10.26623/jic.v3i1.861.

Risuni, Ahmad. Nadzoriyyatul Maqashid 'inda al-Imam Asy-Syatibi. Cairo: International Institute of Islamic Though, 1995.

Sahroni, Oni, and Adiwarman A. Karim. Maqashid Bisnis \& Keuangan Islam : Sintesis Fikih Dan Ekonomi. Jakarta: Rajawali Pers, 2015.

Santoso. "Hakikat Perkawinan Menurut Undang-Undang Perkawinan, Hukum Islam,Dan Hukum Adat." YUDISIA: Jurnal Pemikiran Hukum Dan Hukum Islam 7, no. 2 (2016).

Siregar, Ramadhan Syahmedi. "Dampak Perceraian Yang Tidak Sesuai Dengan Prosedur Perundang-Undangan." FITRAH:Jurnal Kajian Ilmu-ilmu Keislaman $1, \quad$ no. 11 (2015): $161-76$. https://doi.org/10.24952/fitrah.v1i1.333.

Sugiswati, Besse. "Konsepsi Harta Bersama Dari Perspektif Hukum Islam, Kitab Undang-Undang Hukum Perdata Dan Hukum Adat." Perspektif 19, no. 3 (September 28, 2014): 201-11. https://doi.org/10.30742/perspektif.v19i3.22.

Timur, Erma Kartika. "Pembagian Harta Bersama Perkawinan Dalam Perceraian Perkawinan Beda Agama Yang Dicatatkan.” Rechtidee 12, no. 1 (June 30, 2017): 67-83. https://doi.org/10.21107/ri.v12i1.2871.

Wijayanti, Winda. "Kedudukan Istri dalam Pembagian Harta Bersama Akibat Putusnya Perkawinan Karena Perceraian Terkait Kerahasiaan Bank." Jurnal Konstitusi 10, no. 4 (May 20, 2016): 709-30. https://doi.org/10.31078/jk\%x.

Yasin, Akhmad. "Keterkaitan Kerahasiaan Bank dan Pajak: Antara Kepentingan Negara dan Pribadi." Jurnal Konstitusi 16, no. 2 (July 11, 2019): 212-34. https://doi.org/10.31078/jk1621.

Zaini, Iman Jauhari. "Pembagian Harta Perkawinan Poligami Dalam Konteks Hukum Nasional (Studi Kasus Di Mahkamah Syar'iyah Jantho).” Jurnal Ilmu Hukum 1, no. 4 (October 10, 2013). http://jurnal.unsyiah.ac.id/MIH/article/view/4566.

Zubaidi, Zaiyad. "Problematika Pembagian Harta Bersama Di SamalangaBireuen." Jurnal AL-IJTIMAIYYAH: Media Kajian Pengembangan Masyarakat Islam 5, no. 2 (October 9, 2019). https://doi.org/10.22373/alijtimaiyyah.v5i2.4779. 